\title{
Cadmium affects osmotic phase and regulatory volume decrease in cultured human embryonic kidney cells
}

\author{
Rossana Morabito, ${ }^{1}$ Alessia Remigante, ${ }^{1}$ Roberta Costa, ${ }^{2}$ Silvia Dossena, ${ }^{2}$ \\ Giuseppa La Spada, ${ }^{1}$ Angela Marino' \\ 'Department of Chemical, Biological, Pharmaceutical and Environmental Sciences, University of \\ Messina, Messina, Italy; ${ }^{2}$ Institute of Pharmacology and Toxicology, Paracelsus Medizinische \\ Privatuniversität, Salzburg, Austria
}

\begin{abstract}
The present investigation aims to verify whether cadmium $\left(\mathrm{Cd}^{2+}\right)$, a metal possibly accumulated in body tissues from air and food, affects cell volume regulation capability in cultured human embryonic kidney (HEK 293 Phoenix) cells. The osmotic phase (OP), which is the expected cell swelling due to aquaporins involvement after hyposmotic challenge, and regulatory volume decrease (RVD), bringing cell volume back to control values through $\mathrm{Ca}^{2+}$-dependent ion efflux $\left(\mathrm{K}^{+}\right.$and $\left.\mathrm{Cl}^{-}\right)$, have been monitored in HEK 293 cells treated with $\mathrm{Cd}^{2+}(1-10-100 \mu \mathrm{M})$ for different time intervals $(30 \mathrm{~min}, 3 \mathrm{~h}$, overnight) and then submitted to $15 \%$ hyposmotic shock. The results show that both 1 and $10 \mu \mathrm{M} \mathrm{Cd}^{2+}$ significantly reduced $\mathrm{OP}$, whereas $100 \mu \mathrm{M}$ impaired $\mathrm{Cd}^{2+}$ RVD mechanisms. The use of glutathione (GSH, $200 \mu \mathrm{M}$ ) confirmed that $\mathrm{Cd}^{2+}$ elicited its effect via oxidative damage, being RVD inhibition after $\mathrm{Cd}^{2+}$ treatment prevented by this
\end{abstract}

Correspondence: Angela Marino, Department of Chemical, Biological, Pharmaceutical and Environmental Sciences, University of Messina, viale F. Stagno D’Alcontres 31, 98166 Messina, Italy.

Tel: +39.090 .6765214 - Fax: +39.090 .394030 .

E-mail:marinoa@unime.it

Key words: $\mathrm{Cd}^{2+}$; HEK 293 Phoenix cells; Osmotic phase; Regulatory volume decrease; GSH.

Contributions: RM, AR, RC performed the experiments; SD collected and analyzed data; GLS checked the manuscript; AM wrote the manuscript and sought the references.

Conflict of interest: the authors declare no potential conflict of interest.

Received for publication: 27 November 2015.

Revision received: 19 February 2016.

Accepted for publication: 21 March 2016.

CC Copyright R. Morabito et al., 2016

Licensee PAGEPress, Italy

Journal of Biological Research 2016; 89:5650

doi:10.4081/jbr.2016.5650

This article is distributed under the terms of the Creative Commons Attribution Noncommercial License (by-nc 4.0) which permits any noncommercial use, distribution, and reproduction in any medium, provided the original author(s) and source are credited. antioxidant compound. Our findings show that: i) HEK 293 cells are a suitable model to assay the effect of xenobiotics on cell homeostasis; ii) $\mathrm{Cd}^{2+}$, depending on its concentration, affects cell homeostasis at different levels, i.e. water and ion permeability, responsible for, respectively, OP and RVD mechanism, adding thus more information to the knowledge of $\mathrm{Cd}^{2+}$ toxicology.

\section{Introduction}

Heavy metals and their toxic effects on cells and tissues have been widely investigated, as they can be accumulated through respiration, adsorption and ingestion. ${ }^{1,2}$ In this regard, cadmium $\left(\mathrm{Cd}^{2+}\right)$ accumulates in the atmosphere being produced, from one hand, by natural processes such as erosion and abrasion of rocks and soils, forest fires and volcanic eruptions ${ }^{3}$ and, from another hand, by anthropogenic factors due to industrial development ${ }^{4}$ concerning production of pigments, electronic compounds and rechargeable nickel-cadmium batteries. Hence, $\mathrm{Cd}^{2+}$ accumulation in humans may result from water, food and air contaminations. In this regard, cigarette smoking should be also considered as a source of intoxication, due to high $\mathrm{Cd}^{2+}$ concentrations in cigarettes. ${ }^{5}$

$\mathrm{Cd}^{2+}$ in humans may provoke acute or chronic intoxication effects, as already observed in liver, lungs, thyroid, bones, testis and immunity system. Its detrimental effects, reviewed elsewhere, ${ }^{6-8}$ could be associated to its low renal excretion rate, thus contributing to its accumulation in the organism. The effect of $\mathrm{Cd}^{2+}$ on cells has been already described, ${ }^{9-12}$ though this issue has not been completely clarified.

One of the most critical feature for cell survival is the ability of a cell to regulate its volume under osmotic perturbations. ${ }^{13,14}$ In a hyposmotic environment, after the expected initial swelling, termed osmotic phase (OP), cells undergo a regulatory shrinkage through the loss of intracellular solutes, mainly $\mathrm{K}^{+}$and $\mathrm{Cl}^{-}$, along with osmotically obliged water, leading then to regulatory volume decrease (RVD). ${ }^{13,15}$ RVD mechanisms are highly conserved and common to many cells from evolutionary distant species. ${ }^{14,16-18}$ Similarly, the uptake of osmolytes, followed by gain of osmotically obliged water occurs under hypertonic shrinkage, leading to regulatory volume increase (RVI), a process exhibited by many cell types and mainly due to $\mathrm{Na}^{+}$influx. ${ }^{13,14,19}$

Studies on the volume sensor transduction pathway for volume regulation ${ }^{20,21}$ provide evidence for intracellular $\mathrm{Ca}^{2+}$ involvement, protein phosphorylation, arachidonic acid and phosphoinositide turnover, as well as mechanical sensors, such as stretch-activated channels and 
cytoskeleton. These pathways may work together producing an integrated and effective volume regulatory response, ${ }^{22}$ which allows cell adaptation to osmolarity changes of the external medium. Both RVD and RVI processes account for cell viability and homeostasis ${ }^{23}$ and, as already shown in other cell types, ${ }^{24}$ they can be affected by exogenous compounds like pollutants.

On this basis and in an attempt to consolidate RVD response as a tool to monitor cell function under perturbations of the external medium, the aim of the present investigation is to verify whether OP and/or RVD are affected by $\mathrm{Cd}^{2+}$ in human embryonic kidney (HEK 293 Phoenix) cells, chosen as a model of renal cells continuously exposed to hyposmotic and hyperosmotic conditions during the process of urine production, and, therefore, capable of adaptive mechanisms to regulate cell volume. ${ }^{14}$

\section{Materials and Methods}

\section{Human embryonic kidney cells culture}

Human renal HEK 293 Phoenix cells ${ }^{25}$ were kindly provided by Paracelsus Medizinische Privatuniversität (Salzburg, Austria) and frozen in liquid nitrogen before culturing. Cells were seeded in $100 \mathrm{~mm}$ diameter Petri dishes containing $10 \mathrm{~mL}$ of Minimum Essential Eagle Medium (MEM; Sigma Aldrich, St. Louis, M0, USA) supplemented with 10\% fetal bovine serum (FBS; Cambrex Bio Science, East Rutherford, NJ, USA), 2 mM l-glutamine, $100 \mu \mathrm{g} / \mathrm{mL}$ streptomycin, $100 \mathrm{U} / \mathrm{mL}$ penicillin and $1 \mathrm{mM}$ pyruvic acid (sodium salt). Subcultures were routinely established every second to third day by seeding cells into $100 \mathrm{~mm}$ diameter Petri dishes following trypsin/ethylenediaminetetraacetic acid (EDTA) treatment. Cultured cells were placed in an incubator chamber (humidified 95\% air, $5 \% \mathrm{CO}_{2}, 37^{\circ} \mathrm{C}$ ). Confluent cells were detached with $1 \mathrm{~mL}$ trypsin-EDTA solution, re-suspended in $10 \mathrm{~mL}$ of fresh medium and then seeded in $60 \mathrm{~mm}$ diameter Petri dishes, as described below.

In order to perform RVD test, HEK 293 cells were seeded on $18 \times 18$ $\mathrm{mm}$ coverslip glasses, previously placed into $60 \mathrm{~mm}$ diameter Petri dishes, and then grown for $24 \mathrm{~h}$ (humidified $95 \%$ air and $5 \% \mathrm{CO}_{2}$ at $37^{\circ} \mathrm{C}$ ) before the experiment.

At the end of incubation, cells were used for either control or experimental tests after $\mathrm{Cd}^{2+}$ treatment. With regard to control experiments, a single coverslip glass with adherent cells, taken from the $60 \mathrm{~mm}$ diameter Petri dish, was mounted on a slide and used for RVD test. For experimental tests, after $24 \mathrm{~h}$ incubation in $60 \mathrm{~mm}$ diameter Petri dish, $\mathrm{Cd}^{2+}$ at different concentrations (1-10-100 M) was added to the medium and cells incubated for, alternatively, $30 \mathrm{~min}, 3 \mathrm{~h}$ or overnight. Coverslips with adherent cells were then mounted on a slide and used for RVD tests.

\section{Chemicals}

The hyposmotic solution was composed by $\mathrm{NaCl} 125 \mathrm{mM}, \mathrm{CaCl}_{2} 2.5$ $\mathrm{mM}, \mathrm{MgCl}_{2} 2.5$, HEPES $10 \mathrm{mM}$, at $\mathrm{pH} 7.4$ and osmotic pressure 275 $\mathrm{mOsm} / \mathrm{Kg}_{\mathrm{H} 20}$. Isosmotic physiological solution was obtained by adding

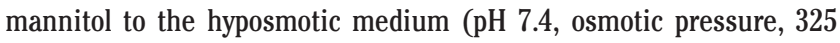
$\mathrm{mOsm} / \mathrm{Kg}_{\mathrm{H} 2 \mathrm{O}}$ ). $\mathrm{pH}$ was measured with an Orion $\mathrm{pH}$-meter. Osmolality of solutions was measured with a Fiske OS osmometer. Stock solutions for either $\mathrm{CdSO}_{4}$ or glutathione (GSH) were dissolved in distilled water. The compound was then added to the experimental solution to yield the final concentrations (1-10-100 $\mu \mathrm{M}$ for $\mathrm{CdSO}_{4}, 200 \mu \mathrm{M}$ for $\left.\mathrm{GSH}\right)$, used on HEK 293 cells. All chemicals were purchased from Sigma Aldrich.

\section{Regulatory volume decrease tests}

To perform RVD tests, a make-shift perfusion chamber was prepared by placing at first two strips of double sided tape (Scotch 3M; 3M, St. Paul, MN, USA) on the long edges of a glass slide, then a $18 \times 18 \mathrm{~mm}$ coverslip with adherent cells and, finally, a $24 \times 32 \mathrm{~mm}$ coverslip. This allowed either isosmotic or hyposmotic solution to be added at one side and absorbed at the other side of the coverslip $24 \times 32 \mathrm{~mm}$ with strips of filter paper, so that they could be rapidly exchanged.

\section{Control tests}

With regard to control RVD tests, the experimental design consisted of three periods: period 1: $\mathrm{pH} 7.4$, isosmotic physiological solution for 5 min; period 2: pH 7.4, hyposmotic physiological solution (15\% hyposmotic shock) for $30 \mathrm{~min}$; period 3: $\mathrm{pH} 7.4$ isosmotic physiological solution for $5 \mathrm{~min}$. Cell volume measurements were taken from cells strongly adherent to the slide. About 40 images/cell were taken, minute-by-minute during the whole experiment, with a phase contrast microscope (Leica DMLS; Leica Microsystems GmbH, Wetzlar, Germany) connected to a video camera (charge-coupled device digital camera) and a computer equipped with suitable software (Movie Maker; Microsoft, Redmond, WA, USA). Since each chosen cell was considered as a sphere, the diameter (needed to calculate cell volume) of each recorded image was measured (Image J; http://imagej.net/) as a function of time. The results were then expressed as the relative volume $-V N_{0}$ - where $V$ and $V_{0}$ represent, respectively, the volume of a cell at a given time and the average of volume of the same cell in isosmotic physiological solution.

\section{Regulatory volume decrease test on cadmium-treated cells}

RVD tests on $\mathrm{Cd}^{2+}$-treated cells were performed upon cell viability assessment by Trypan blue dye exclusion test (Sigma Aldrich). Concentrations and time of exposure to this metal have been chosen according to what reported by Bertin and Averbeck. ${ }^{6}$ As no cell damage was seen, treated cells, after incubation with $\mathrm{Cd}^{2+}(1$ or 10 or $100 \mu \mathrm{M})$ for, respectively, $30 \mathrm{~min}-3 \mathrm{~h}$ - overnight, were used for RVD test according to the following protocol: $\mathrm{pH} 7.4$, isosmotic physiological solution for 5 min (period 1); $\mathrm{pH} \mathrm{7.4,} \mathrm{hyposmotic} \mathrm{physiological} \mathrm{solution}$ (15\% hyposmotic shock) for $30 \mathrm{~min}$ (period 2); pH 7.4 isosmotic physiological solution for 5 min (period 3 ). Image analysis was performed as described for control tests.

\section{Regulatory volume decrease test on glutathione-cadmium-treated cells}

To possibly counteract the effect of $\mathrm{Cd}^{2+}$ on RVD, cells were pretreated with the antioxidant GSH (reduced glutathione, $200 \mu \mathrm{M}$ ). With this aim, HEK 293 cells, after overnight incubation, were treated with $200 \mu \mathrm{M} \mathrm{GSH}$ for 20 min before adding either 1 or 10 or 100 $\mu \mathrm{M} \mathrm{Cd}^{2+}$. After incubation for $30 \mathrm{~min}-3 \mathrm{~h}$ - overnight, RVD test and image analysis were performed according to the protocol reported above for control tests.

\section{Statistical analysis}

Statistical analysis was performed using GraphPad Prism (version 5.03; GraphPad Software Inc., San Diego, CA, USA). The results are expressed as means \pm standard error of means. Comparisons among groups were performed with Student's $t$ test and, for multiple comparisons, with two-way analysis of variance (ANOVA), followed by Bonferroni's post-hoc test. Statistically significant differences were assumed at $\mathrm{P}<0.05\left({ }^{*} \mathrm{P}<0.05\right.$ low significance, ${ }^{* *} \mathrm{P}<0.01$ medium significance, ${ }^{* * *} \mathrm{P}<0.001$ high significance). $N$ represents the number of independent experiments. Statistical analysis was reported in Table 1 and, accordingly, on graph panels and legends. 


\section{Results}

\section{Control tests}

Untreated cells exposed to the hyposmotic shock (Figure 1) exhibited the expected swelling, reaching a $V N_{0}$ peak value of $1.294 \pm 0.025$, within 4 min of the hyposmotic challenge. This $\mathrm{V}_{0}$ value was significantly higher than that observed in the isosmotic period ( $1^{\text {st }}$ period, ${ }^{* * *} \mathrm{P}<0.001$ ), consistent with the OP. After the peak value, being unchanged the external medium, cell volume decreased towards the control values, reaching, at the end of the hyposmotic period a $V / N_{0}$ value of $1.030 \pm 0.016$, significantly lower than the $\mathrm{V}_{0}$ peak value $\left(2^{\text {nd }}\right.$ period, $\S \S \$ \mathrm{P}<0.001$ ) and comparable to the $\mathrm{V}_{0}$ observed in the isosmotic period, thus showing $90 \%$ RVD capability. Once replaced the hyposmotic medium with an isosmotic one, to restore the control conditions ( $3^{\text {rd }}$ period), cell volume was brought back to the initial values. No post-RVD RVI was detected within the observation time chosen for the test.

\section{Cadmium treatment}

Cell integrity assessment by Trypan blue dye exclusion test was performed on $\mathrm{Cd}^{2+}$-treated cells before RVD experiments, to exclude any possible cell damage. Neither cells exposed for $30 \mathrm{~min}$, nor for $3 \mathrm{~h}$ or overnight to $\mathrm{Cd}^{2+}$ at all concentrations (1-10-100 M) exhibited damage.

\section{Treatment with $1 \mu \mathrm{M}$ cadmium}

HEK 293 cells treated with $1 \mathrm{M} \mathrm{Cd}^{2+}$ for 30 min (Figure $2 \mathrm{a}$ ), $3 \mathrm{~h}$ (Figure 2b) or overnight (Figure 2c) exhibited the OP after the hyposmotic challenge, reaching a $\mathrm{V} / \mathrm{V}_{0}$ peak value of, respectively, $1.158 \pm 0.015$ ( $2^{\text {nd }}$ period, Figure $\left.2 a\right), 1.192 \pm 0.016\left(2^{\text {nd }}\right.$ period, Figure $2 b), 1.180 \pm 0.021$ ( $2^{\text {nd }}$ period, Figure $2 c$ ). This is significantly higher than the $\mathrm{V} / \mathrm{N}_{0}$ measured in isosmotic conditions ( $\left.{ }^{* * *} \mathrm{P}<0.001\right)$, while it is significantly lower than the $\mathrm{V} / \mathrm{N}_{0}$ peak value observed in untreated cells $\left({ }^{\circ 0} \mathrm{P}<0.001\right.$, Figure $2 \mathrm{a} ;{ }^{\circ} \mathrm{P}<0.01$, Figure $2 \mathrm{~b}$ and $\left.\mathrm{c}\right)$. The $\mathrm{V} / \mathrm{N}_{0}$ peak value observed in both treated and control cells, at any time of incubation, was observed within 5 min of hypotonic shock application $\left(2^{\text {nd }}\right.$ period). At the end of the hyposmotic period ( $2^{\text {nd }}$ period) in each experimental condition (30 min, $3 \mathrm{~h}$, overnight), cell volume decreased to a $\mathrm{V} \mathrm{N}_{0}$ value of, respectively, $1.030 \pm 0.009$ (30 min treatment, $2^{\text {nd }}$ period, Figure $2 \mathrm{a}), 1.025 \pm 0.0025$ ( $3 \mathrm{~h}$ treatment, $2^{\text {nd }}$ period, Figure $2 \mathrm{~b}$ ), $1 \pm 0.002$ (overnight treatment, $2^{\text {nd }}$ period, Figure $2 \mathrm{c}$ ), which is signifi-

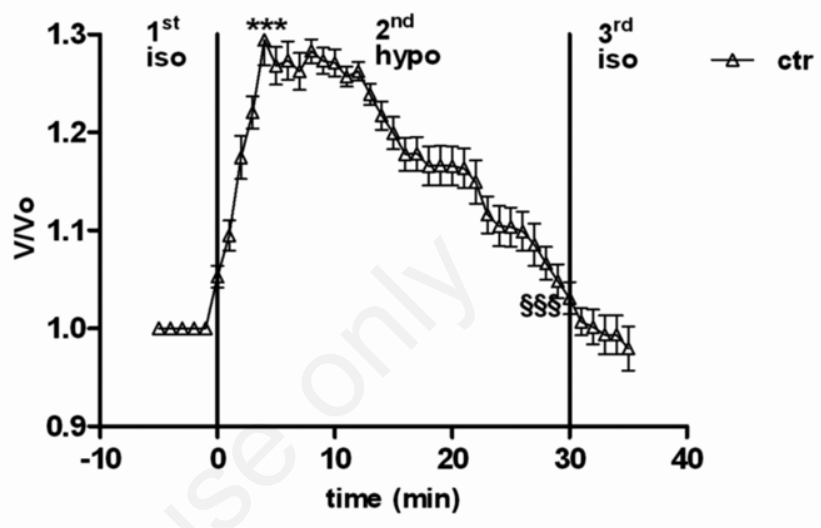

Figure 1. Relative volume $\left(\mathrm{V} / \mathrm{V}_{0}\right)$ of cells measured after exposure to isosmotic ( $1^{\text {st }}$ and $3^{\text {rd }}$ period) and hyposmotic ( $2^{\text {nd }}$ period) solution ( $15 \%$ shock). The peak value in hyposmotic solution was significantly higher than in isosmotic solution $\left({ }^{* * *} \mathrm{P}<0.001\right)$, while it was significantly lower at the end of the $2^{\text {nd }}$ period $\left({ }^{(S S} \mathrm{P}<0.001\right)$.

Table 1. Relative volume in human embryonic kidney cells measured in control conditions or treated with either cadmium at different concentrations (1-10-100 $\mu \mathrm{M})$, with or without $200 \mu \mathrm{M}$ glutathione, and at different incubation times (30 min, $3 \mathrm{~h}$, overnight).

\begin{tabular}{|c|c|c|c|c|}
\hline Experimental condition & $1^{\text {st }}$ period (isotonic) & $\begin{array}{c}\mathrm{V} / \mathrm{N}_{0} \\
2^{\text {nd }} \text { period (hyposmotic) } \\
\text { - peak value }\end{array}$ & $\begin{array}{c}2^{\text {nd }} \text { period (hyposmotic) } \\
\text { - last value }\end{array}$ & N \\
\hline Control & $1.000 \pm 0.015$ & $1.294 \pm 0.025^{* * *}$ & $1.030 \pm 0.016^{\S \S \S}$ & 15 \\
\hline $\begin{array}{l}1 \mu \mathrm{M} \mathrm{Cd}^{2+} \\
30 \mathrm{~min} \\
3 \mathrm{~h} \\
\text { Overnight }\end{array}$ & $\begin{array}{l}1.000 \pm 0.015 \\
1.000 \pm 0.002 \\
1.000 \pm 0.001\end{array}$ & $\begin{array}{l}1.158 \pm 0.025^{* * *, \infty} \\
1.192 \pm 0.016^{* * . \circ} \\
1.180 \pm 0.021^{* *, \circ}\end{array}$ & $\begin{array}{l}1.030 \pm 0.009^{\S \S \S} \\
1.025 \pm 0.025^{\S \S \S} \\
1.000 \pm 0.002^{\S \S \S}\end{array}$ & $\begin{array}{l}13 \\
14 \\
16\end{array}$ \\
\hline $\begin{array}{l}10 \mu \mathrm{M} \mathrm{Cd}^{2+} \\
30 \mathrm{~min} \\
3 \mathrm{~h} \\
\text { Overnight }\end{array}$ & $\begin{array}{l}1.000 \pm 0.001 \\
1.000 \pm 0.005 \\
1.000 \pm 0.001\end{array}$ & $\begin{array}{l}1.119 \pm 0.0025^{* *, \infty, 00} \\
1.138 \pm 0.013^{* * *, 000} \\
1.138 \pm 0.012^{* * *, 0 \circ}\end{array}$ & $\begin{array}{c}1.030 \pm 0.009^{\S \S \S} \\
1.043 \pm 0.007 \S \S \S \\
1.010 \pm 0.0014^{\S \S \S}\end{array}$ & $\begin{array}{l}13 \\
14 \\
14\end{array}$ \\
\hline $\begin{array}{l}100 \mu \mathrm{M} \mathrm{Cd}^{2+} \\
30 \mathrm{~min} \\
3 \mathrm{~h} \\
\text { Overnight }\end{array}$ & $\begin{array}{l}1.000 \pm 0.003 \\
1.000 \pm 0.003 \\
1.000 \pm 0.002\end{array}$ & $\begin{array}{c}1.210 \pm 0.0025^{* * * \circ}, \\
1.213 \pm 0.013^{* * * \circ}, \\
1.246 \pm 0.012^{* *, \text { ns }}\end{array}$ & $\begin{array}{c}1.033 \pm 0.009 \S \S \S, \text { ns } \\
1.131 \pm 0.007 \S \S, \# \# \\
1.178 \pm 0.014^{\S \S, \# \#} \\
\end{array}$ & $\begin{array}{l}18 \\
17 \\
16\end{array}$ \\
\hline $\begin{array}{l}200 \mu \mathrm{M} \mathrm{GSH}+100 \mu \mathrm{M} \mathrm{Cd}^{2+} \\
30 \mathrm{~min} \\
3 \mathrm{~h} \\
\text { Overnight }\end{array}$ & $\begin{array}{l}1.000 \pm 0.002 \\
1.000 \pm 0.002 \\
1.000 \pm 0.002\end{array}$ & 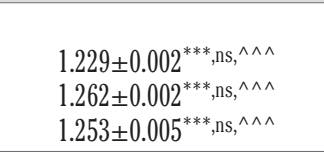 & $\begin{array}{l}1.063 \pm 0.005^{\S \S \S,+++} \\
1.071 \pm 0.020^{\S \S \S,+++} \\
1.112 \pm 0.007^{\S \S \S,+++}\end{array}$ & $\begin{array}{l}17 \\
19 \\
15\end{array}$ \\
\hline
\end{tabular}

$\mathrm{V} N_{0}$, relative volume; $\mathrm{V}$, volume of a cell at a given time; $\mathrm{V}_{0}$, the volume of a cell at a given time and the average of volume of the same cell in isosmotic physiological solution; $N$, number of independent experiments; GSH, glutathione; ns, not significant. Data are presented as means \pm standard error of mean from separate $N$ experiments, where: ${ }^{* * *} \mathrm{P}<0.001$ significantly different compared to isotonic; ${ }^{\$} \$ \mathrm{P}<0.001$ or ${ }^{\S \S} \mathrm{P}<0.01$ significantly different compared to peak value; ${ }^{\circ 00} \mathrm{P}<0.001$ and ${ }^{\circ 0} \mathrm{P}<0.01$ significantly different compared to control; ${ }^{\wedge \wedge} \mathrm{P}<0.001$ significantly different compared to $100 \mu \mathrm{M}$ Cd ${ }^{2+}$-treated cells; $200 \mu \mathrm{M}$ GSH $+100 \mu \mathrm{M} C d^{2+}$ 30 min ns compared to peak value after $100 \mu \mathrm{M} \mathrm{Cd^{2 } + ;}+++\mathrm{P}<0.001$ significantly different compared to $\mathrm{Cd}^{2+}$-treated cells; ${ }^{\# \# \# ~} \mathrm{P}<0.001$ significantly different compared to last hyposmotic value in untreated cells, as determined by two way ANOVA followed by Bonferroni's post-hoc test or paired Student's $t$ test. 
cantly lower than $\mathrm{V} / \mathrm{N}_{0}$ peak value observed in each experimental condition $\left({ }^{\S \S \S} \mathrm{P}<0.001\right)$, thus showing, respectively, $80.3,87,100 \%$ RVD capability. Once restored the isosmotic medium ( $3^{\text {rd }}$ period), cell volume was totally recovered (Figure 2a-c).

\section{Treatment with $10 \mu \mathrm{M}$ cadmium}

After exposure of HEK 293 cells to $10 \mu \mathrm{M} \mathrm{Cd}^{2+}$ for $30 \mathrm{~min}, 3 \mathrm{~h}$ and overnight, $\mathrm{OP}$ was observed after hyposmotic challenge, reaching a $\mathrm{V} / \mathrm{N}_{0}$ value of, respectively, $1.119 \pm 0.0025$ ( $2^{\text {nd }}$ period, Figure $3 \mathrm{a}$ ), $1.138 \pm 0.013\left(2^{\text {nd }}\right.$ period, Figure $\left.3 \mathrm{~b}\right), 1.138 \pm 0.012\left(2^{\text {nd }}\right.$ period, Figure $3 c)$, i.e. significantly higher than values observed in the isosmotic period $\left({ }^{* *} \mathrm{P}<0.01\right.$, Figure $3 \mathrm{a} ;{ }^{* * *} \mathrm{P}<0.001$, Figure $3 \mathrm{~b}$ and $\mathrm{c}$ ), and significantly lower than the $\mathrm{V} / \mathrm{N}_{0}$ peak value observed in untreated cells $\left({ }^{\circ \circ} \mathrm{P}<0.001\right)$. At the end of the hyposmotic period ( $2^{\text {nd }}$ period $)$, cell volume decreased to a $V / N_{0}$ value of, respectively, $1.030 \pm 0.009$ (Figure $3 \mathrm{a}$ ),
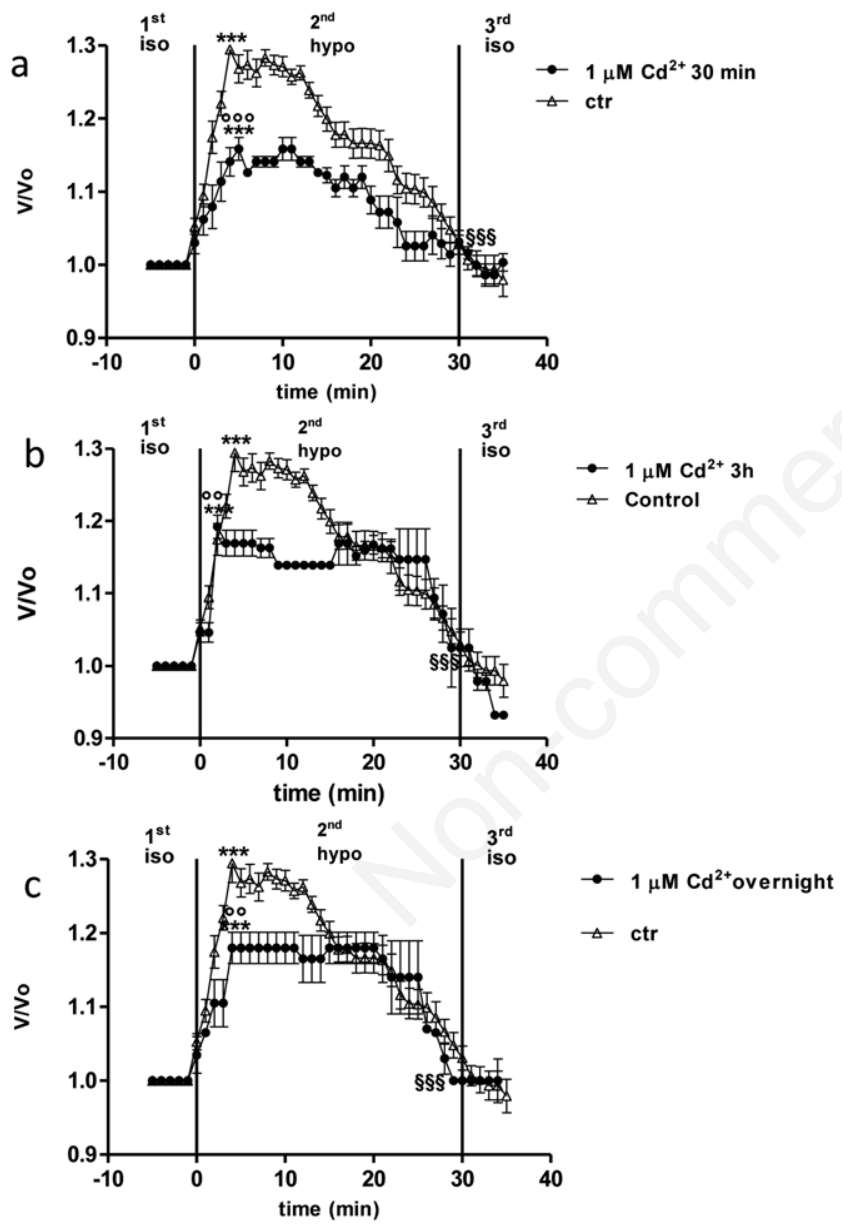

Figure 2. Relative volume $\left(\mathrm{V} / \mathrm{V}_{0}\right)$ of cells exposed to $15 \%$ hyposmotic shock after treatment with $1 \mu \mathrm{M} \mathrm{Cd}^{2+}$ for $30 \mathrm{~min}$ (a), $3 \mathrm{~h}$ (b), or overnight (c). Comparison with control cells (ctr) is also provided. The peak value in hyposmotic medium ( $2^{\text {nd }}$ period) was significantly higher than in isosmotic solution $\left({ }^{* * *} \mathrm{P}<0.001\right)$, and significantly lower than in control cells $\left({ }^{\circ 0 \circ} \mathrm{P}<0.001\right)$. At the end of the $2^{\text {nd }}$ period, $V / \mathrm{V}_{0}$ in treated cells was significantly lower than the peak value $\left({ }^{(S \$} \mathbb{P}<0.001\right)$ at any incubation time.
$1.043 \pm 0.007$ (Figure 3b), $1.010 \pm 0.0014$ (Figure 3c), which is significantly lower than the peak value $\left(\S^{\S} \mathrm{P}<0.001\right)$, showing, respectively, 74, 69 and 93\% RVD capability. The $\mathrm{VN}_{0}$ peak value observed in $\mathrm{Cd}^{2+}$ treated cells (at any incubation time) was reached within 10 min of hypotonic shock, significantly later than in untreated cells. Once restored the isosmotic medium ( $3^{\text {rd }}$ period), cell volume was brought back to control values (Figure 3a-c).

\section{Treatment with $100 \mu \mathrm{M}$ cadmium}

HEK 293 cells exposed to $100 \mu \mathrm{M} \mathrm{Cd}{ }^{2+}$ for $30 \mathrm{~min}, 3 \mathrm{~h}$ or overnight exhibited $\mathrm{OP}$ after the hyposmotic challenge, reaching a $\mathrm{V} / \mathrm{N}_{0}$ value of, respectively, $1.210 \pm 0.0025\left(2^{\text {nd }}\right.$ period, Figure $\left.4 \mathrm{a}\right), 1.213 \pm 0.013\left(2^{\text {nd }}\right.$ period, Figure 4b), $1.246 \pm 0.012$ ( $2^{\text {nd }}$ period, Figure $4 \mathrm{c}$ ), significantly higher than values observed in isotonic period $\left({ }^{* * *} \mathrm{P}<0.001\right)$ and significantly lower than the $\mathrm{V} / \mathrm{N}_{0}$ peak value observed in untreated cells
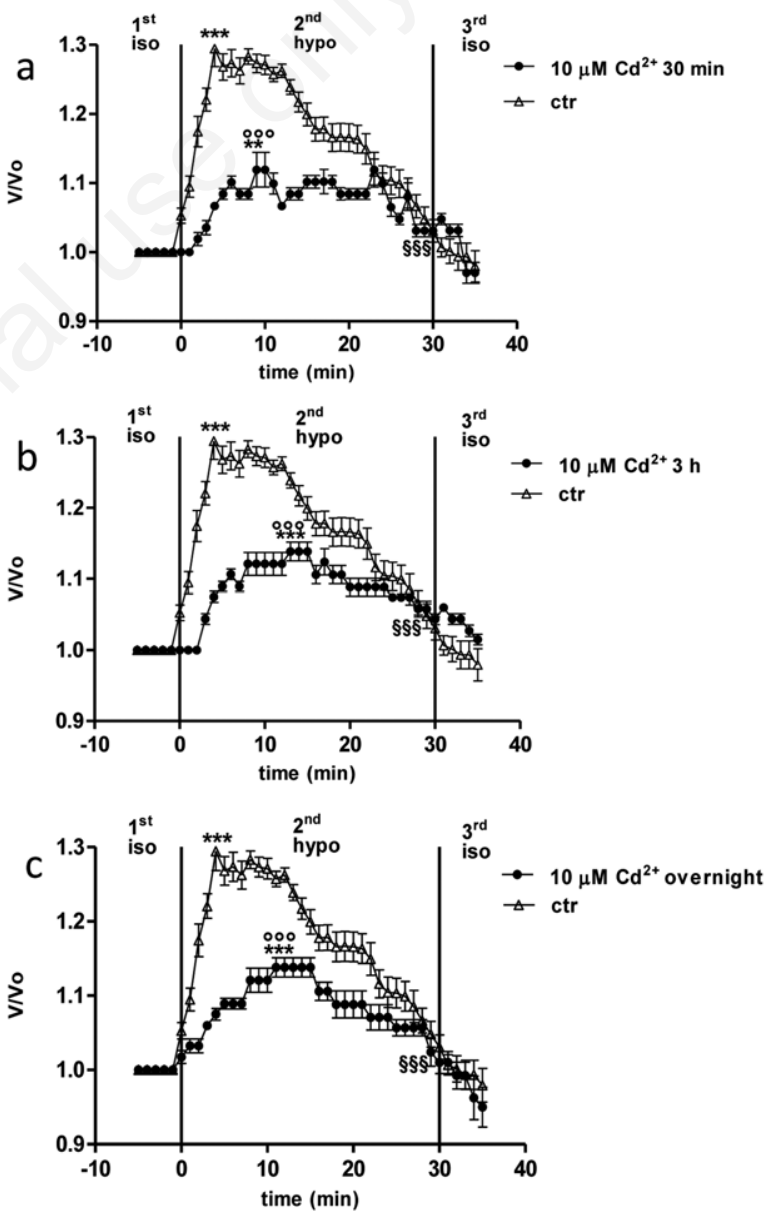

Figure 3. Relative volume $\left(\mathrm{V} / \mathrm{V}_{0}\right)$ of cells exposed to $15 \%$ hyposmotic shock after treatment with $10 \mu \mathrm{M} \mathrm{Cd}^{2+}$ for $30 \mathrm{~min}(\mathrm{a}), 3 \mathrm{~h}$ (b), or overnight (c). Comparison with control cells (ctr) is also provided. The peak value in hyposmotic medium $\left(2^{\text {nd }}\right.$ period) was significantly higher than in isosmotic solution $\left({ }^{* *} \mathrm{P}<0.01\right.$ at 30 min, ${ }^{* * *} \mathbf{P}<0.001$ at both $3 \mathrm{~h}$ and overnight), and significantly lower than in control cells $\left({ }^{\circ}{ }^{\circ} \mathrm{P}<0.001\right)$. At the end of the same period, $\mathrm{V} / \mathrm{V}_{0}$ was significantly lower than the peak value $\left({ }^{\$ S} \mathbb{S}<0.001\right)$ at any incubation time. 
$\left({ }^{\circ} \mathrm{P}<0.05\right.$, Figure $4 \mathrm{a}$ and b). $\mathrm{V} / \mathrm{N}_{0}$ peak value observed in overnight 100 $\mathrm{M} \mathrm{Cd}^{2+}$-treated cells was not significant with respect to control cells. At the end of the hyposmotic period ( $2^{\text {nd }}$ period), cell volume decreased to a $V / N_{0}$ value of, respectively $1.033 \pm 0.009$ (Figure $3 \mathrm{a}$ ), $1.131 \pm 0.007$ (Figure $3 \mathrm{~b}$ ), $1.178 \pm 0.014$ (Figure $3 \mathrm{c}$ ) significantly lower than the $\mathrm{V} / \mathrm{V}_{0}$

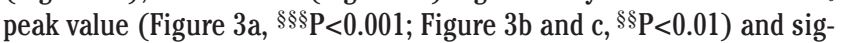
nificantly higher than that one measured in untreated cells only after 3 $\mathrm{h}$ and overnight treatment $\left({ }^{\# \#} \mathrm{P}<0.01\right.$ and ${ }^{\# \#} \mathrm{P}<0.001$, respectively), showing, respectively, 74, 69 and $93 \%$ RVD capability. The $\mathrm{V}_{0}$ peak value in $\mathrm{Cd}^{2+}$-treated cells was reached within 5 min of hypotonic shock at $30 \mathrm{~min}$ or $3 \mathrm{~h}$, comparable to control conditions, while, on the other hand, it was reached within 10 min of hypotonic shock after overnight
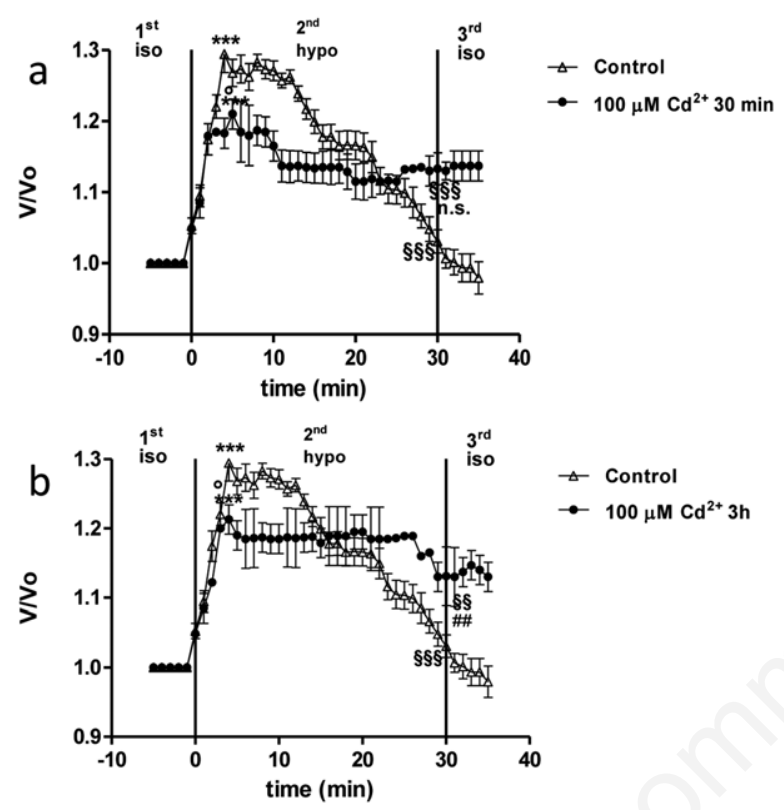

- $100 \mu \mathrm{M} \mathrm{Cd}^{2+} 3 \mathrm{~h}$

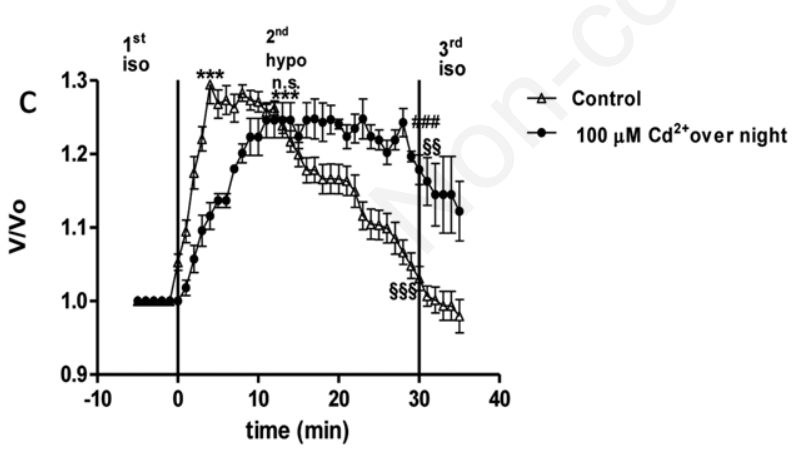

Figure 4. Relative volume (V/V $)$ of cells exposed to $15 \%$ hyposmotic shock after treatment with $100 \mu \mathrm{M} \mathrm{Cd}^{2+}$ for $30 \mathrm{~min}(\mathrm{a}), 3$ h (b), or overnight (c). Comparison with control cells (ctr) is provided. The peak value in hyposmotic medium ( $2^{\text {nd }}$ period) was significantly higher than in isosmotic solution $\left({ }^{* * *} \mathrm{P}<0.001\right) . \mathrm{V} / \mathrm{V}_{0}$ at the end of the $2^{\text {nd }}$ period in treated cells was significantly lower than the peak value (a, ${ }^{\mathfrak{S} S} \mathrm{P}<0.001 ; b, c,{ }^{\mathfrak{S}} \mathrm{P}<0.01$ ), while it was significantly higher than the last value in untreated cells (\#\# $\mathrm{P}<\mathbf{0 . 0 0 1}$ ). In cells treated for both $30 \mathrm{~min}$ and $3 \mathrm{~h}$, the peak value was significantly lower than in control $\left(a, c,{ }^{\circ} \mathrm{P}<0.05\right)$, while, after overnight treatment, it was not significantly different with respect to control $(b, \mathrm{~ns})$. treatment, significantly later than in untreated cells. Once restored the isosmotic medium ( $3^{\text {rd }}$ period), cell volume was not brought back to control values (Figure $4 \mathrm{a}-\mathrm{c}$ ) within the time of observation chosen for the present protocol.

\section{Treatment with $200 \mu \mathrm{M}$ glutathione}

In a separate set of experiments, $200 \mu \mathrm{M}$ GSH as an antioxidant compound was used to possibly counteract the inhibitory action of $\mathrm{Cd}^{2+}$ $(10-100 \mu M)$ on OP and/or RVD. Since cell response of both 10 and 100 $\mathrm{Cd}^{2+}$-treated cells to $\mathrm{GSH}$ application was comparable, data from 100 $\mu \mathrm{M} \mathrm{Cd}^{2+}$ plus $200 \mu \mathrm{M}$ GSH experiments have been depicted in Figure 5. GSH alone $(200 \mu \mathrm{M})$ did not damage HEK 293 cells and both OP and
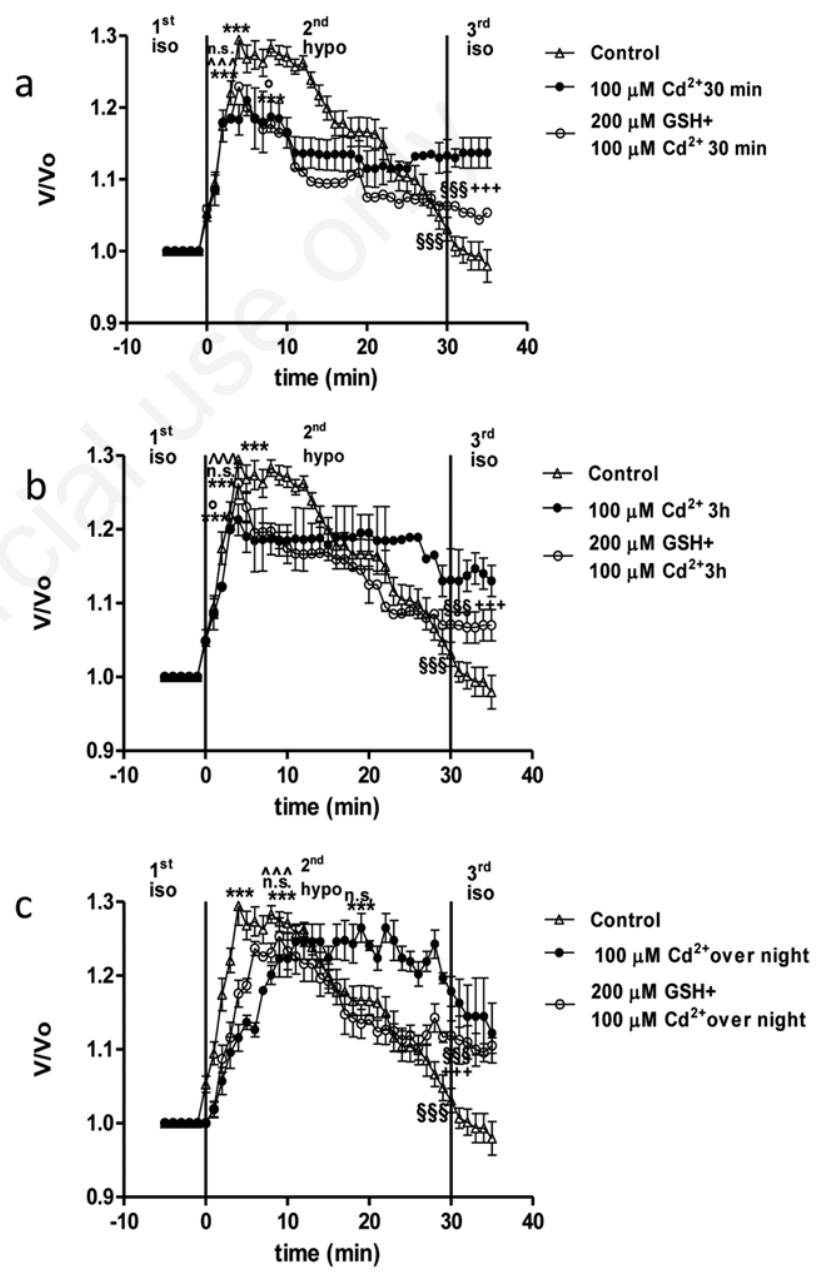

Figure 5. Relative volume $\left(\mathrm{V} / \mathrm{V}_{0}\right)$ of cells exposed to $15 \%$ hyposmotic shock after treatment with $200 \mu \mathrm{M}$ glutathione (GSH) plus $100 \mu \mathrm{M} \mathrm{Cd}{ }^{2+}$ for $30 \mathrm{~min}$ (a), $3 \mathrm{~h}$ (b), or overnight (c). Comparison with both control cells (ctr) and $\mathrm{Cd}^{2+}$-treated cells is also provided. Peak value of GSH-Cd ${ }^{2+}$-treated cells at any time of incubation was significantly different with respect to $\mathrm{Cd}^{2+}$ treated cells $\left({ }^{\wedge \wedge \wedge} \mathrm{P}<\mathbf{0 . 0 0 1}\right)$, while not significantly different with respect to untreated cells. At the end of the hyposmotic challenge in $\mathrm{GSH}-\mathrm{Cd}^{2+}$-treated cells, $\mathrm{V} / \mathrm{V}_{0}$ was significantly lower than peak value $\left({ }^{\$} \$ \mathbb{P}<0.001\right)$ and significantly different with respect to what observed in both $\mathrm{Cd}^{2+}$-treated and control cells $\left({ }^{+++} \mathbf{P}<0.001\right)$. 
RVD exhibited after hyposmotic shock application were comparable to those observed in untreated cells, at any time of incubation (30 min, 3 h or overnight; data not shown). HEK 293 cells exposed to $200 \mu \mathrm{M} \mathrm{GSH}$ plus $100 \mu \mathrm{M} \mathrm{Cd}^{2+}$ for $30 \mathrm{~min}, 3 \mathrm{~h}$ or overnight, after hyposmotic shock application swelled reaching a $\mathrm{V} / \mathrm{N}_{0}$ peak value of, respectively, $1.229 \pm 0.002$ (Figure 5a), $1.262 \pm 0.002$ (Figure 5b), $1.253 \pm 0.005$ (Figure $5 c)$, significantly higher than $\mathrm{V} / \mathrm{N}_{0}$ observed in isosmotic conditions $\left({ }^{* *} \mathrm{P}<0.001\right)$. The $\mathrm{VN}_{0}$ peak value of $\mathrm{GSH}-\mathrm{Cd}^{2+}$ treated cells, at any time of incubation was significantly higher than that one observed in $\mathrm{Cd}^{2+}$-treated cells $\left({ }^{\wedge \wedge} \mathrm{P}<0.001\right)$ while not significant with respect to $\mathrm{V} / \mathrm{N}_{0}$ peak value of control cells. At the end of the hyposmotic challenge in $\mathrm{GSH}-\mathrm{Cd}^{2+}$-treated cells, cell volume decreased to a $\mathrm{V}_{0}$ value of, respectively, $1.063 \pm 0.005$ (Figure 5a) $1.071 \pm 0.020$ (Figure 5b), $1.112 \pm 0.007$ (Figure 5c), significantly lower than peak value $(\S \S \S<0.001)$ and significantly different with respect to what observed in both $\mathrm{Cd}^{2+}$-treated cells and control condition $\left({ }^{+++} \mathrm{P}<0.001\right)$, showing, respectively 72.5, 73.3 and 50\% RVD capability. Once restored isosmotic conditions ( $3^{\text {rd }}$ period), $\mathrm{V}_{0}$ was only partially recovered in both GSH$10 \mu \mathrm{M} \mathrm{Cd}^{2+}$ - and GSH-100 $\mu \mathrm{M} \mathrm{Cd}^{2+}$-treated cells.

\section{Discussion}

It has been shown that long-term environmental exposure of cells to $\mathrm{Cd}^{2+}$ results in high blood levels of this metal, which is associated with organ-specific toxic effects and distinct pathologies in a variety of tissues and organs, including kidney. ${ }^{26}$ In this regard, the proximal tubule as well as renal glomeruli, exposed to circulating metals during plasma filtration, have been recognized as a major target in $\mathrm{Cd}^{2+}$-induced effects. $^{27-29}$

On this basis, cultured human embryonic kidney (HEK 293 Phoenix) cells have been chosen as a model to define whether heavy metals like $\mathrm{Cd}^{2+}$, deriving from environmental pollution, ${ }^{4}$ may affect cell volume regulation under hyposmotic shock, a homeostatic parameter recognized to be essential for survival of many cells. ${ }^{13,30}$ Being renal cells continuously exposed to physiological changes in the osmolarity of the external medium, ${ }^{31}$ cell lines derived from kidney are a suitable model for monitoring homeostatic cell functions, such as the regulation of cellular volume, in the presence of xenobiotics. ${ }^{32,33}$

Our results show that HEK 293 cells exhibit the expected OP within 4 min of $15 \%$ hyposmotic challenge, leading to water influx, as shown in other cell types. ${ }^{18}$ After OP, RVD phase occurs and is completed within 30 min of hyposmotic shock application, with cell volume recovering, due to both $\mathrm{K}^{+}$and $\mathrm{Cl}^{-}$outflow, resulting in water efflux. ${ }^{18,30}$

Here we demonstrate that time exposure comprised between 30 min and overnight did not induce cell death under either 1 or 10 or $100 \mu \mathrm{M}$ $\mathrm{Cd}^{2+}$. Furthermore, both 1 and $10 \mu \mathrm{M} \mathrm{Cd}^{2+}$-treated HEK 293 cells did not exhibit a peak value comparable to that observed in untreated cells. This result provides evidence for an inhibition of OP inhibition presumptively due to aquaporins, ${ }^{18,34,35}$ rather than an inhibition of RVD mechanisms, suggesting thus a possible action of the metal on water flux. On the other hand, OP was preserved in $100 \mu \mathrm{M} \mathrm{Cd}^{2+}$-treated HEK 293 cells, while RVD inhibited, suggesting a possible action of the metal on ion transport, namely both $\mathrm{K}^{+}$and $\mathrm{Cl}^{-}$flux, playing a major role in RVD response. ${ }^{13}$

The evidence that sensitivity to $\mathrm{Cd}^{2+}$ varies from one cell type to another and that $\mathrm{Cd}^{2+}$ toxic effect highly depends on its concentration, duration of exposure and tissues/cells target, has been already demonstrated. ${ }^{6}$ This point implies that multiple effects on cells after $\mathrm{Cd}^{2+}$ exposure can be considered. In this regard, $\mathrm{Cd}^{2+}$, at concentrations above $1 \mu \mathrm{M},{ }^{36}$ has been described to affect cell cycle progression, proliferation, differentiation, DNA replication and repair as well as apop- totic pathways. ${ }^{37}$ However, at lower concentrations, it seems to enhance DNA synthesis and cell proliferation. ${ }^{38}$

As concerns the inhibition of OP and/or RVD phase after $\mathrm{Cd}^{2+}$ exposure, some authors have already correlated the effect of heavy metals to cell membrane transport, hence supporting our hypothesis that both ion and water movement may be modified after exposure to $\mathrm{Cd}^{2+}$. Metals have been shown to inhibit epithelial $\mathrm{Na}^{+}$channels (ENaC) ${ }^{39}$ mainly through Cys and His, possibly after internalization of this metal. In this respect, it has been reported that $\mathrm{Cd}^{2+}$ may compete with $\mathrm{Ca}^{2+}$ uptake through $\mathrm{Ca}^{2+}$ channels ${ }^{40}$ and not through $\mathrm{Cd}^{2+}$-specific uptake pathways, being $\mathrm{Cd}^{2+}$ uptake reduced by $\mathrm{Ca}^{2+}$ channel blockers in several cell types. ${ }^{9}$ Moreover, $\mathrm{Cd}^{2+}$ has been demonstrated to enter mitochondria via $\mathrm{Ca}^{2+}$ transport pathways, ${ }^{41}$ so that the site of action of $\mathrm{Cd}^{2+}$ seems to be inside the mitochondria, the major source of reactive oxygen species (ROS) production. ${ }^{42} \mathrm{As}$ a matter of fact, $\mathrm{Cd}^{2+}$ toxicity may be associated to ROS induction, ${ }^{43}$ even though the mechanism of their formation, not occurring via $\mathrm{Cd}^{2+}$ triggered fenton-like reaction, is yet unknown. ${ }^{44}$

It has been already shown that $\mathrm{Cd}^{2+}$ doses lower than $50 \mu \mathrm{M}$ lead to increased $\mathrm{H}_{2} \mathrm{O}_{2}$ levels as early as 5 min after exposure with a maximum at $15 \mathrm{~min}$, affecting membranes permeability. On this basis, we may suggest that $\mathrm{Cd}^{2+}$-induced inhibition of RVD mechanisms may rely on an oxidative damage targeting HEK 293 cell membrane. Investigations on $\mathrm{Cd}^{2+}$-induced $\mathrm{ROS}$ also reveal an increase in both superoxide anion $\left(\mathrm{O}_{2}{ }^{-}\right)$and $\mathrm{H}_{2} \mathrm{O}_{2}$ levels in HeLa and bovine endothelial cells, under 1-20 $\mu \mathrm{M} \mathrm{Cd}{ }^{2+}$ concentrations. ${ }^{43}$ Shih and co-authors ${ }^{45}$ confirmed these results and assessed that in normal human lung fibroblasts (MRC5) $\mathrm{H}_{2} \mathrm{O}_{2}$ is 2.9-fold elevated after $3 \mathrm{~h}$ of $\mathrm{Cd}^{2+}$ treatment.

Previous data obtained on HEK 293 cells treated with $\mathrm{H}_{2} \mathrm{O}_{2}$ in isosmotic conditions ${ }^{46}$ clearly show a cell volume decrease, putatively due to ion loss and obliged water efflux, considered as an early stage of the apoptotic process. ${ }^{47}$ Since in the present investigation an impaired swelling capacity under hyposmotic challenge was seen under both 1 and $10 \mu \mathrm{M} \mathrm{Cd}^{2+}$ treatment, an oxidative effect of the metal comparable to what observed by $\mathrm{H}_{2} \mathrm{O}_{2}$-treated HEK 293 cells may be even suggested.

In addition to its role as a generator of ROS, $\mathrm{Cd}^{2+}$ may also affect antioxidative enzymes that play an important role in ROS elimination. In this respect, in normal rat liver cell line, high concentrations of $\mathrm{Cd}^{2+}$ (100-300 $\mu \mathrm{M})$, after 4 or $8 \mathrm{~h}$ exposure, have been demonstrated to reduce the activity of antioxidant enzymes such as catalase and glutathione reductase as well as reduced and oxidized glutathione. The reduction in glutathione levels after $\mathrm{Cd}^{2+}$ administration has been also shown in mice. ${ }^{48}$ Other studies demonstrate a relationship between $\mathrm{Cd}^{2+}$ exposure and lipid peroxidation, as reported in skeletal muscle cells $\mathrm{C} 2 \mathrm{C} 12$, where oxidation of lipids occurs at concentrations of $\mathrm{Cd}^{2+}>7.5 \mu \mathrm{M} .{ }^{49}$ Lipid peroxidation may cause cross-linking and polymerization of membrane components, ${ }^{50}$ affecting thus lipid composition of cell membranes and, in turn, cell functions.

As reviewed by Bertin and Averbeck ${ }^{6}$, metallothioneins and glutathione can mainly detoxify $\mathrm{Cd}^{2+}$ in cells. Reduced-glutathione levels, observed after intoxication, may be brought about by the affinity of $\mathrm{Cd}^{2+}$ to thiol groups and may be responsible for the decrease in cellular antioxidant activities. Both events, i.e. the reduction of both metallothionein expression and glutathione levels, enhance cellular injury due to $\mathrm{Cd}^{2+}$ exposure. On this basis, GSH has been here used as an antioxidant compound to treat cells before $\mathrm{Cd}^{2+}$ application, similarly to what already performed in $\mathrm{H}_{2} \mathrm{O}_{2}$-treated HEK 293 cells. ${ }^{46}$ In this latter case $200 \mu \mathrm{M}$ GSH was effective in impairing cell shrinkage due to $\mathrm{H}_{2} \mathrm{O}_{2}$. Since in the present experiments $200 \mu \mathrm{M}$ GSH impairs the inhibitory effects of $\mathrm{Cd}^{2+}$ (at both 10 and $100 \mu \mathrm{M}$, at any time of $\mathrm{Cd}^{2+}$ treatment), we may support the hypothesis that $\mathrm{Cd}^{2+}$ may affect cell function acting via oxidizing events such as glutathione levels reduction. 


\section{Conclusions}

The present investigation would add information about the effect that heavy metals, such as $\mathrm{Cd}^{2+}$, may exert on a cell target, demonstrating that: i) renal cells, usually exposed to metabolites and toxicants, are confirmed as a good model for investigating the impact of heavy metals at cellular level; ii) RVD capability has been revealed as a suitable tool to verify the effect of both short and long term exposure to the metal; iii) the effect of $\mathrm{Cd}^{2+}$ on HEK 293 cells depends on both time of exposure to the metal and on metal concentration; iv) both $\mathrm{OP}$, depending on aquaporins involvement, and RVD, depending on $\mathrm{K}^{+}$and $\mathrm{Cl}^{-}$ fluxes, are affected by $\mathrm{Cd}^{2+} ; \mathrm{v}$ ) though no mechanism of action is here proposed to explain $\mathrm{Cd}^{2+}$ effect, the use of GSH as antioxidant compound significantly reduced RVD alterations due to $\mathrm{Cd}^{2+}$ exposure.

\section{References}

1. Manriquez AR, Magaña PI, López V, Guzmán R. Biosorption of $\mathrm{Cu}$ by Thiobacillus ferrooxidans. Bioprocess Eng 1998;18:113-8.

2. Zhou JL, Salvador SM, Liu YP, Sequeria M. Heavy metals in the tissues of dolphins (Delphinus delphis) stranded on the Portuguese coast. Sci Total Environ 2001;273:61-76.

3. Marcano LBC, Carruyo IM, Montiel XM, et al. Effect of cadmium on cellular viability in two species of microalgae (Scenedesmus sp. and Dunaliella viridis). Biol Trace Elem Res 2009;130:86-93.

4. Jarup L. Hazards of heavy metal contamination. Brit Med Bull 2003;68:167-82.

5. Tsutsumi R, Hiroi H, Momoeda M, et al. Induction of early decidualization by cadmium, a major contaminant of cigarette smoke. Fertil Steril 2009;91:1614-7.

6. Bertin G, Averbeck D. Cadmium: cellular effects, modifications of biomolecules, modulation of DNA repair and genotoxic consequences (a review). Biochimie 2006;88:1549-59.

7. Jancic SA, Stosic BZ. Cadmium effects on the thyroid gland. Vitam Horm 2014;94:391-425.

8. Marettová E, Maretta M, Legáth J. Toxic effects of cadmium on testis of birds and mammals: a review. Anim Reprod Sci 2015;155:1-10.

9. Souza V, Bucio L, Gutiérrez-Rui MC. Cadmium uptake by a human hepatic cell line (WRL-68 cells). Toxicology 1997;120:215-20.

10. Foulkes EC. Transport of toxic metal across cell membranes. P Soc Exp Biol Med 2000;223:234-40.

11. Gobe G, Crane D. Mitochondria, reactive oxygen species and cadmium toxicity in the kidney. Toxicol Lett 2010;198:49-55.

12. Hernández-García A, Romero D, Gómez-Ramírez P, et al. In vitro evaluation of cell death induced by cadmium, lead and their binary mixtures on erythrocytes of common buzzard (Buteo buteo). Toxicol In Vitro 2014;28:300-6.

13. Lang F. Mechanisms and significance of cell volume regulation. J Am Coll Nutr 2007;26;613-23.

14. Hoffman EK, Lambert IH, Pedersen SF. Physiology of cell volume regulation in vertebrates. Physiol Rev 2009;89:193-277.

15. Pasantes-Morales H, Lezama RA, Ramos-Mandujano G, Tuz KL. Mechanisms of cell volume regulation in hypo-osmolality. Am J Med 2006;119:4-11.

16. La Spada G, Marino A, Sorrenti G. Anatomical and physiological characteristics of tentacular nematocytes isolated by different methods from Aiptasia diaphana (Cnidaria: Anthozoa) of the brackish pond Faro (Messina, Italy). In: Faranda FM, Guglielmo L, Spezie G, eds. Structure and processes in the Mediterranean ecosystems. Berlin: Springer Verlag; 2001. pp 297-303.
17. Marino A, Morabito R, La Spada G, et al. Mechanisms of hyposmotic volume regulation in isolated nematocytes of the anthozoan Aiptasia diaphana. Cell Physiol Biochem 2010;26:209-18.

18. Marino A, Morabito R, La Spada G, et al. Evidence for aquaporinmediated water transport in nematocytes of the jellyfish Pelagia noctiluca. Cell Physiol Biochem 2011;28:1211-8.

19. Marino A, La Spada G. Regulatory volume increase in nematocytes isolated from acontia of Aiptasia diaphana (Cnidaria, Anthozoa). Cell Mol Biol 2004;50:533-42.

20. Stutzin A, Hoffmann EK. Swelling-activated ion channels: functional regulation in cell-swelling, proliferation and apoptosis. Acta Physiol 2006;187:27-42.

21. Wehner F. Cell volume-regulated cation channels. Contrib Nephrol 2006;152:25-53.

22. Pedersen SF, Kapus A, Hoffmann EK. Osmosensory mechanisms in cellular and systemic volume regulation. J Am Soc Nephrol 2011;22:1587-97.

23. Lang F, Ritter M, Völkl H, Häussinger D. The biological significance of cell volume. Renal Physiol Bioch 1993;16:48-65.

24. Morabito R, Marino A, La Spada G. Heavy metals affect Regulatory Volume Decrease (RVD) in nematocytes isolated from the jellyfish Pelagia noctiluca. Comp Biochem Phys A 2013;165:199-206.

25. Di Ciommo DP, Duckett A, Burcescu I, et al. Retinoblastoma protein purification and transduction of retina and retinoblastoma cells using improved alphavirus vectors. Invest Ophth Vis Sci 2004;45: 3320-9.

26. Teeyakasem W, Nishijo M, Honda R, et al. Monitoring cadmium toxicity in a Thai population with high level environmental exposure. Toxicol Lett 2007;169:185-95.

27. Uriu K, Kaizu K, Komine N, et al. Renal hemodynamics in rats with cadmium-induced nephropathy. Toxicol Appl Pharm 1998;150:76-85.

28. Nordberg GF. Historical perspectives on cadmium toxicology. Toxicol Appl Pharm 2009;238:192-200.

29. Templeton DM, Liu Y. Multiple roles of cadmium in cell death and survival. Chem-Biol Interact 2010;188:267-75.

30. Hoffmann EK, Pedersen SF. Cell volume homeostatic mechanisms: effectors and signaling pathways. Acta Physiol 2011;202:465-85.

31. Zarogiannis SG, Ilyaskin AV, Baturina GS, et al. Regulatory volume decrease of rat kidney principal cells after successive hypo-osmotic shocks. Math Biosci 2013;244:176-87.

32. Prozialeck WC, Edwards JR. Mechanisms of cadmium-induced proximal tubule injury: new insights with implications for biomonitoring and therapeutic interventions. J Pharmacol Exp Ther 2012;343:2-12.

33. Fujiwara Y, Lee JY, Tokumoto M, Satoh M. Cadmium renal toxicity via apoptotic pathways. Biol Pharm Bull 2012;35:1892.

34. Carbrey JM, Agre P. Discovery of the aquaporins and development of the field. Handb Exp Pharmacol 2009;190:3-28.

35. Ishibashi K, Kondo S, Hara S, Morishita Y. The evolutionary aspects of aquaporin family. Am J Physiol-Reg I 2011;300:566-76.

36. Misra UK, Gawdi G, Pizzo SV. Induction of mitogenic signalling in the 1LN prostate cell line on exposure to submicromolar concentrations of cadmium. Cell Signal 2003;15:1059-70.

37. Dong S, Shen HM, Ong CN. Cadmium-induced apoptosis and phenotypic changes in mouse thymocytes. Mol Cell Biochem 2001;222:11-20.

38. Von Zglinicki T, Edwall C, Ostlund E, et al. Very low cadmium concentrations stimulate DNA synthesis and cell growth. J Cell Sci 1992;103:1073-81.

39. Yu L, Douglas CE, Helms MN. Effect of divalent heavy metals on epithelial Na+ channels in A6 cells. Am J Physiol-Renal 2007;293: 236-44.

40. Gagnon E, Hontela A, Jumarie C. Reciprocal inhibition of Cd and 
Ca uptake in isolated head kidney cells of rainbow trout (Oncorhynchus mykiss). Toxicol In Vitro 2007;21:1077-86.

41. Martelli A, Rousselet E, Dycke C, et al. Cadmium toxicity in animal cells by interference with essential metals. Biochimie 2006;88: 1807-14.

42. Raha S, Robinson S. Mitochondria, oxygen free radicals, disease and ageing. Trends Biochem Sci 2000;25:502-8.

43. Szuster-Ciesielska A, Stachura A, Slotwinska M, et al. The inhibitory effect of zinc on cadmium-induced cell a poptosis and reactive oxygen species (ROS) production in cell cultures. Toxicology 2000; 145:159-71.

44. Ercal N, Gurer-Orhan H, Aykin-Burns N. Toxic metals and oxidative stress part I: mechanisms involved in metal-induced oxidative damage. Curr Top Med Chem 2001;1:529-39.

45. Shih CM, Ko WC, Wu JS, et al. Mediating of caspase-independent apoptosis by cadmium through the mitochondria-ROS pathway in MRC-5 fibroblasts. J Cell Biochem 2004;91:384-97.
46. Morabito R, La Spada G, Dossena S, Marino A. Oxidative stress affects responsiveness to hypotonicity of renal cells. J Biol Res 2014;87:4811.

47. Antico S, Lionetto MG, Giordano ME, et al. Cell volume regulation and apoptotic volume decrease in rat distal colon superficial enterocytes. Cell Physiol Biochem 2013;32:1551-65.

48. Karmakar R, Banerjee A, Datta S, Chatterjee M. Influence of cadmium intoxication on hepatic lipid peroxidation, glutathione level, and glutathione S-transferase and gamma-glutamyl transpeptidase activities: correlation with chromosome aberrations in bone marrow cells. J Environ Pathol Tox 1999;18:277-87.

49. Yano CL, Marcondes MC. Cadmium chloride-induced oxidative stress in skeletal muscle cells in vitro. Free Radical Biol Med 2005;39:1378-84.

50. Spatz L. Introduction. In: Spatz L, Bloom AD, eds. Biological consequences of oxidative stress. New York, NY: Oxford University Press; 1992. pp 3-22. 